\section{Two views of the new Germany}

SIR - The comments of Frits L. Meijler ( $\mathrm{Na}$ ture 350, 268; 1991) on the purported German character are hurtful in two ways: (1) It is horrible to see how deeply he has been hurt, and still feels; (2) I resent his presenting a harsh verdict, then acknowledging that $\mathrm{E}$. Guthy (Nature 348, 670; 1990) did his best but claiming that Guthy did not have a right to say what he did because he is German. In effect, the accused is not allowed to defend himself because he is being accused.

Meijler is a generation older than I am, judging from his letter. For me, things do look different. It is my firm belief that, if there is a common strain among Germans born after 1950 , it is a constant if unexpressed awareness of Auschwitz. It has pervaded the political thinking of my generation to such an extent that many foreigners consider its effects rather strange. A friend of mine once remarked, "What Germans cannot understand is that I can say, I am an American, and I just don't feel bad about it". I learned only when I went to the United States that other peoples do not have a taboo on national feelings. Germans do, even after 9 November 1989, because 9 November 1938 is by no means forgotten. If there are some groups of thoughtless people, such as those who threw stones at Poles when the border was opened for them this week, they are a reason for concern, like the soccer hooligans in Great Britain; but if there is anything typical in the incident, it is the immediate sense of alarm in the public reaction.

If Meijler related his personal feelings on that matter, may I relate mine? How it is to grow up, becoming slowly aware of a horrible past, learning that there is a cause of great shame although I had not done anything wrong? Knowing that my father fought in Hitler's army, from loyalty to his country, as is today considered normal in any other country but Germany? I left Europe, in part to leave all this behind. To no avail.

Around the age of 15 , I was told that one can tell a Jew by the look on his face. I was outraged, thought this to be a racist opinion. Then in Califormia I met a very beautiful young woman with a face unlike any I had ever seen before. One day I saw in a bookstore a book of photographs, apparently taken by an SS officer at the ramps in Auschwitz. There were long columns of people, bearded men with hats, then a closeup of the first row of the women - and there was my friend's face, six times, with the knowledge of death in their eyes.

Nothing reveals the backward direction of Meijler's view more than the use of the phrase "Grossdeutschland". All right, Germany won the soccer championship last year, so what? No peoples are more eager to get along with their neighbours than Germany, precisely because of what happened to Meijler's parents. Regaining a sense of national feeling is probably a healthy process.
When the borders opened on that day in November, I felt that an incredible burden had been taken from me which I had been carrying for so long that I did not feel it any more. I was utterly surprised at myself. What I observe now among the public is not an exaggerated sense of pride, but rather a sense of being 'all right' again.

A more genuine reason for concern now perhaps is that the former East Germans are not used to dealing with people from other nations. They definitely react in a different way from Westerners to Turks, Yugoslavs and Poles. They will have to learn.

FaLK Koenemann

Institut für Mineralogie, RWTH, D-5100 Aachen, Germany

SIR - I read with interest the striking article on "Germany in perspective" by E. Guthy about a revival of prejudice against Germans based now on German "national or racial characteristics". It is surprising but true that at this stage of development in genetics such articles are not only desirable but indeed very much needed. Even among scientists there are still some who tend to forget that neither a German nor for that matter a Jewish gene was ever sequenced.

During the pre-Nazi and Nazi period, the most famous champions of the Nazi 'genetics' were the German university professors E. Fischer and Othmar von Verschuer. They accepted as a dogma the superior 'national and racial' characteristics of Germans and taught that the social, cultural and political activities of some religious and/or ethnic mitherefore forced sterilization or 'elimination' norities is justified. Now, apparently, some try to explain German politics in the same but reverse vein by assuming the existence of a malicious 'German gene'. It would appear that the Fischer-Verschuer obscurantism in genetics (and that of their ambitious postdoc Josef Mengele) is still alive and kicking even among those with a scientific background. After all, the very same von Verschuer remained for almost 20 years an active university professor of 'anthropology' and genetics in post-war Germany (cf. Benno Müller-Hill The Murderous Science, Oxford University Press, 1989). For such reasons Guthy's wise words should be doubly appreciated.

On the other hand, I share the concerns of W. Frank Harris and of J. F. MacKenzie (Nature 347, 510; 1990) that, with the new economic power and without the constraints of partition, the destructive and inhuman forces of the past might loom up in the postBittburg Germany, although I would not look for their origins in a 'German DNA'. It is true, for instance, that Chancellor Helmut Kohl organized a wreath-laying ceremony on SS graves in Bittburg in the 1980s, but this was not genetically predetermined. norities are genetically predetermined and (that is, robbery and murder) of certain mi-
Many other frightening academic and political phenomena (as the Verschuer and Bittburg cases) were tolerated during the four-and-a-half decades of post-war developments in Germany. One can therefore understand the concerns (mentioned in your leading article in Nature 346, 203; 1990) of Mrs Margaret Thatcher and the group of academic historians, who "wondered whether some of the unhappy (German) characteristics of the past might reemerge in 10 or 20 years with just as destructive consequences". It is not irrelevant in this connection that the facilities for manufacture of poisonous gas in Libya, Iraq and Syria were provided by (among others) contemporary German technology and business, albeit run by indigenous talent. I do not accept the theory that this could have been done while the German authorities were sleeping. Neither do I believe that a 'German DNA' is responsible.

The differences between Guthy's and Mrs Thatcher's perspectives on Germany arise from a different approach to the problem. Guthy in his article covers centuries, whereas Mrs Thatcher is influenced by living memory. I gladly agree with Guthy that the past centuries of glorious German history are a guarantee for the future glorious centuries. The question remains of what is going to happen in the next 10 to 20 years. There are many good reasons for optimism as well as for anxiety and vigilance.

University of British Columbia, Department of Pharmacology \&

Therapeutics,

Faculty of Medicine,

2176 Health Sciences Mall,

Vancouver, BC, Canada V6T 1W5

\section{Mix-up}

SIR - I read with interest the book review by Joseph F. Sambrook about genomic genomes (Nature 349, 752; 1991). My father, Lionel Penrose (1898-1972), geneticist and friend of Frances Partridge, might well have felt flattered to be taken for Sir Francis Galton (1822-1911), who was a founder of human genetics.

It was only in 1956 that the number of human chromosomes was clearly shown to be 23 pairs, and the chromosomal abnormality in Down's syndrome was found to be trisomy 21 in 1959.

Guy's Hospital,

SHIRLEY HODGSON

Division of Medical and Molecular

Genetics,

7 th \& 8th Floors, Guy's Tower,

St Thomas Street, London SE1 9RT, UK

\section{Correction}

In the letter entitled "Early case of AIDS in the USA" (Nature 347, 509; 1990), the authors should have been listed as both R. F. Garry (Tulane University) and M. H. Witte (University of Arizona). 